\title{
Developing a Working Typology of Rural Criminals: From a UK Police Intelligence Perspective
}

ROBERT SMITH

Reader in entrepreneurship

SIPR Lecturer in leadership and management

Aberdeen Business School

The Robert Gordon

ABERDEEN

Contact author: Robert Smith: r.smith-a@rgu.ac.uk; +44 [0]1224 263922

\begin{abstract}
This article develops a working typology of rural criminal types in a UK wide context. It considers strategies used by these diverse ideal-typologies of rural criminals to successfully evade the police intelligence apparatus. It demonstrates hidden links between illegal rural enterprise and local criminal networks whilst concentrating upon the intersection of traditional criminality and illegal entrepreneurship. This article explores the changing landscape of rural crime, positing new entrepreneurial strategies for tackling rural criminality in its myriad forms.
\end{abstract}

Keywords: Illegal Rural Enterprise, Rural Criminal Entrepreneurship, Rural Policing Methodologies 


\section{Introduction}

This article develops a working typology of rural criminal types in a UK wide context. The article and the typology of rural criminals which emerges is written from the perspective of UK police, and is intended to be of assistance to those officers and employees of government agencies who are responsible for the investigation of crime. The article also utilizes the extant literature, although small, to describe types of rural criminals. Traditionally, rural policing has received scant attention from criminologists (Fenwick, Docknell, Slade \& Roberts, 2011) and indeed, Yarwood and Gardner (2000) highlighted the paucity of research on rural crime and policing issues in general. Moreover, such research as there is into rural crime and criminality has tended to focus upon the police as the key agency and this has influenced perceptions on rural crime. Policing rural areas is a challenging activity due to the often conflicting demands on police resources. Issues, such the deskilling of the rural beat officer, and the inexorable closure of rural police stations, taken in juxtaposition with the rise in urban criminality combine to create a vacuum in the countryside which the criminally and entrepreneurially inclined exploit for their ends (Smith, 2010). Whilst the withdrawal of policing resources from the countryside may appear to be justifiable when framed in terms of efficiency and the reallocation of resources to meet more pressing priorities, the actions appear to have had unforeseen consequences in creating an intelligence gap. As a result of 'operational overstretch', the police may be ill prepared for interdicting such atypical entrepreneurial criminal types. There is also a discernable gap in literature on rural criminality and thus rural criminals as well as there being a considerable diversity in what constitutes rural crime. Clearly, a more integrated approach is necessary which entails alliance building with other agencies operating in rural areas with a law enforcement role. This has led academics such as Carter et al (1982), to make a plea for the integration of research into rural crime.

Indeed, research into the notion of 'The Rural Criminal' has not advanced much since the early works of Tönnies (1887; 1957), Sorokin and Zimmerman (1929), Sorokin, Zimmerman and Galpin (1931), and Clinard (1942, 1944, \& 1960). Tönnies was one of the first sociologists to consider the distinction between the psychosocial status of the urban and the rural criminal. Tönnies considered crime to be a manifestation of the system of capitalism and divided the criminal classes into rogues and offenders. Indeed, he coined the term 'rougery' to cover those crimes which were motivated by financial gain and considered rouges as criminals driven by the profit motive. Interestingly, he found that statistically the majority of rogues operated out of urban enclaves. Conversely, he considered offenders to be driven by the underside of the capitalist ethic whereby they were its brutalized victims driven to crime via poverty, despair, and circumstance. His theories mirror the modern push versus pull theories of entrepreneurship. The studies of Sorokin and Zimmerman (1929) and Sorokin, Zimmerman and Galpin (1931) extended this work, highlighting the lower crime rates in rural areas which they argued may be an artifact of the lower density of policing than of the rural idyll. What is interesting about the work of Tönnies and his contemporaries is that they viewed the urban as a fractured society and 
the rural as a cohesive one. In this system, the farmer was viewed as a separate psychosocial capitalist class and it is this fact which may account for the different manifestations of crime in urban and rural areas. Nevertheless, Tönnies did not discount the existence of rogues operating from rural areas.

Moreover, there appears to be no agreed definition of what constitutes rural criminality or for that matter the rural criminal. The conventional stereotype of the criminal in rural Britain is that of the urban working class male. Indeed, Claydon (2011) in her study of "The Detective, the Criminal and the Countryside" looked to examine the place of rural Britain in the criminal landscape and came to the conclusion that in the majority of British media representations of criminals in rural settings that visualize criminality was normally signified by virtue of masculinity and the otherness or via the expression of an urban working class identity. However, as will be seen, the stereotype of the urban marauder (Paulson, 2007) can be misleading.

This article also highlights the roles of 'Illegal Rural Enterprise' (McElwee, Smith, Sommerville, 2011) and the 'Enterprise Orientated Criminal' (Hobbs, 1998) in rural settings. Nevertheless, policing is not an activity one normally associates with enterprise, especially rural policing. Thus, as well as policing traditionally accepted forms of rural criminality, the police must now deal with new forms of criminal behaviours and practices. Despite the seminal work of Hobbs (1998) in relation to the enterprising criminal in an urban context, studies such as those of Williams (2006) into the hidden enterprise culture in a rural context are rare. This is particularly so in relation to conceptualizing rural criminal entrepreneurship (Davis \& Potter, 1991). This study thus provides an alternative portrait of illegal enterprise commingled with criminality in rural Britain.

In light of the above, a working typology of rural criminals would prove to be beneficial to academics and practitioners alike. Therefore, this study extends this call by arguing that this synthesis requires 'to take' account of entrepreneurship theory and rural enterprise culture. Consequentially, the aim of this article is to present a developing, working typology of rural criminals in a UK wide context, and to investigate the policing of the contemporary informal rural economy (Williams, 2006). In particular, it acknowledges the growth of rural criminal entrepreneurship (Davis \& Potter, 1991) and seeks to investigate and explain the circumstances which combine to assist these diverse ideal-typologies of rural criminals who evade the police intelligence apparatus. This article therefore explores the changing landscape of rural crime and examines new entrepreneurial strategies for tackling rural criminality in its myriad forms and in the process works towards developing a new model of rural policing. The purpose of this dialogical exercise is not to prove or disprove a particular criminological or enterprise based thesis, merely to highlight the changing landscape of rural crime and criminality and where each typology of rural criminal fits into the landscape. 
This work also extends the emerging literature on rural criminal entrepreneurship (see McElwee, 2009; McElwee, Smith \& Sommerville, 2011; Smith, 2004; Smith, 2008; Smith, 2009; Smith, 2011, Smith, 2013; Smith \& McElwee, 2013). As will be demonstrated the changing geographies of rural policing have affected how the informal rural economy is policed and by whom. By adopting a holistic approach, it is possible to view crime and enterprise to be part of the same social dimension (vis' a vis' Baumol, 1990) albeit that traditionally they have been regarded as separate entities. The primary purpose of this article is to explore an important aspect of policing the informal rural economy whilst revealing the emerging links between illegal rural enterprise and local criminal networks which have resulted from the changing geographies and demographics of policing. In synthesizing this with an understanding of what this means in practical policing terms in respect of police intelligence gathering activities, the paper makes a significant contribution. In the process, we must concentrate upon the intersection of traditional criminality and illegal entrepreneurship and the practicalities of policing the rural domain. This is a strange but relevant trinity.

The remainder of this article consists of the following sections. The next section takes cognizance of the literature on policing rural crime with a particular focus on how it relates to the British context whilst placing rural policing in a traditional context by considering different crime types associated with rural criminality including entrepreneurial criminality and the links between enterprise and criminality, building up a holistic picture of rural criminality. Thereafter, the following section develops the 'taxonomy' of contemporary rural criminal types. The final section offers some concluding thoughts.

\section{Reviewing the Literature on Policing Rural Crime}

Prior to conducting the review of the literature proper, it is incumbent upon the author to provide a brief overview of the system of rural policing in a UK context. In the UK there is a universal system of policing based around autonomous policing areas each under the command of a Chief Constable. Operationally, no distinction is made between urban and rural policing albeit the former is prioritized in terms of policing resources because most of the reported crime occurs in urban areas. Police officers responsible for policing rural areas receive no special training for their role and officers in rural areas tend to be those of the rank of Constable. Many have little experience of dealing with rural crimes and there is a high turnover rate with officers moved from urban to rural areas and vice versa after short periods of service. As a result there are few officers who remain in a rural setting for the period of their policing careers. Also of importance, is the fact that there are few dedicated detective officers in rural areas who have knowledge of rural crime or criminals. These basic facts of policing life underpin the development of the criminal types which have evolved as a result of the influence of culture and ecology. The proximity of large, urban centres and the clustering of rural residents and farmers in villages give rise to the myth of the urban marauder preying on a vulnerable idyllic community as discussed below. 
Many published studies into rural criminality and rural policing have their origins in Australia, New Zealand and the United States (for example, see the studies of Bristow,1982; Buttle, 2006; O'Connor and Gray, 1989; Thurman \& McGarrell, 1997; Weisheit 1999; Weisheit $\&$ Falcone, undated). Nevertheless, the cultural similarities between these cognate studies and the British context makes them of relevance from a British perspective because many aspects of rural crime and policing are generic and are equally applicable to all western cultures. It is also significant that many of these are (1) books; and / or (2) compendiums of collected papers. From a perusal of such texts it is apparent that from a practical perspective there is a considerable body of knowledge in respect of rural crime and policing. This is also significant from a policing perspective because as a general rule rural police officers do not receive any theoretical input nor, even a basic training in rural policing practices or methodologies.

Nevertheless, there is a small but growing body of academic studies of rural policing in Britain including the studies of Yarwood (2000), Yarwood and Cozens (2004), Mawby (2004), Mawby (2007), Smith (2010), and Fenwick et al, (2011). Such works and in particular the works of Yarwood and Mawby tackle the subject at a theoretical, conceptual and ideological level. Conversely, this paper will approach the subject from a practical policing perspective because it is at this level that an updated understanding of typologies of rural criminals can best make a contribution. Elsewhere, Smith (2010) has articulated that policing rural areas is a challenging activity at the best of times due to the contemporary (and often conflicting) demands on police resources. Issues such the deskilling of the rural beat officer and the inexorable closure of rural police stations as a response to the rise in urban criminality may combine to create a vacuum in the countryside which the criminally and entrepreneurially inclined can exploit for their benefit.

\section{Placing Rural Policing in a Traditional Context}

Rural policing is an integral part of policing per se (Donnelly, 2005). Nevertheless, there is a common perception in the media that crime is rare in rural communities (Yarwood, 2005). Another common misperception is that there is not an indigenous rural criminal class and that crime is an urban phenomenon. This has significant implications in terms of policing because it suggests that if there are no rural criminal classes, then the role of the police in rural areas is to act as guardians of the rural community, thereby protecting them from criminals from urban areas. That is not to say that there are not 'rural crime hotspots' (Mawby, 2007). Alongside this misperception, there is also a dubious assumption that because the pace of life is slower in rural areas, the police merely need to maintain a presence to achieve their objectives. Rural policing is seen as being a metaphorical 'backwater' in which there is little need for change. Indeed, BairdOlson (2000) sum up this police attitude as a case of 'Doing what we've always done'. As will be demonstrated, this is an outdated outlook. To exacerbate matters there is a wide discrepancy in relation to how rural areas are policed and indeed the nature of their job roles (Maguire $e t a l$, 1991). As a career option rural policing is not accorded the status of other mainly urban policing 
activities. As a result it is not regarded as a career enhancing posting nor a specialism which requires specific training. This malaise is quite common.

Moreover, Brogden (1999) has noted a tendency for academics and social commentators to conflate the literatures of community policing, rural, and small town policing resulting in a hagiographic and nostalgic image of community policing as 'cherry pie'. From a British perspective, Mawby (2004) also comments on this halcyon image of rural policing. Thus from the outset there is a danger in situating rural policing in a nostalgic context which has little to do with the dynamics of change in rural communities, both in the context of crime and enterprise. Payne, Berg and Sun (2005) highlight the common (derogatory) perception of rural policing as being about 'dogs, drunks, disorder, and dysfunction'. Although the perception of the efficiency and effectiveness of the police as held by the rural public is generally more favourable than in urban areas, there is still nevertheless a negative perception of police-public community relations. Indeed, Mawby (2004) argues that rural dwellers were critical of certain aspects of policing, particularly the inaccessibility of the police as a public service. One of the key complaints is the inaccessibility of police in rural areas, thus establishing a local permanent police presence is vital. This can be done by re-opening small police stations on a part-time basis, or by sharing accommodation with other emergency services, or community centres, libraries, village halls or schools. In such locations the provision of drop-in services and information can create a tangible presence alongside regular officers, specials and volunteers.

This highlights the importance of the changing geographies of policing - namely the fear of crime in rural communities. Yarwood (2000) goes as far as to refer to the 'miserable countryside'. Indeed, fear of crime is a recurring theme in research (Benedict, 2000; Crank, Giacomazzj, \& Heck, 2003; Hogg, 2005; Yarwood, 2000). Hogg (2005) refers to these changes as a 'rural crises' but acknowledges that hysterical responses to rural crime emerge from time to time.

Rural policing is a complex phenomenon (Buttle, 2006) because paradoxically it is both a definable entity and a metaphysical concept which has its own philosophies, ideologies and perhaps even its own mindset. Fenwick et al (2011) argue that it has its own unique set of knowledge and practices. Indeed, it involves the engagement with diverse policing typologies such as those of farm crime, wildlife crime, and the policing of villages. Consequentially, the skill sets required of the rural police officer differ from those of the urban crime fighter. As stated above it is significant that studies of rural policing are rare (Yarwood, 2000: Mawby, 2000). Studies relating to intelligence gathering in rural areas are even rarer.

\section{The Police Intelligence Apparatus in Rural Settings}

We must consider the police intelligence apparatus in rural settings. A particular focus of this paper relates to the contemporary police intelligence gathering apparatus in Britain and in particular in relation to how aspects of rural criminality sit in reference to the National 
Intelligence Model [NIM] (John \& Maguire, 2004). NIM is an intelligence led policing methodology (Ratcliffe, 2003) that has revolutionized the way policing is conducted in Britain by providing a template for all forces to conduct their day to day business. It is to this practical purpose that the direction of this paper is orientated. It is acknowledged that the police intelligence apparatus is urban focused (John \& Maguire, 2004). This urban focus is intelligence driven and aimed at addressing the more pressing priorities identified via the NIM Model in dealing with organized crime groups. Urban crime is classified as real crime and rural crime as other. Indeed, there is no nationally agreed definition of what constitutes rural crime. As a consequence, the police gather only a small percentage of intelligence from rural areas and have adopted an integrated, multi-agency approach which entails building alliances with other established rural agencies with a policing role as well as with neighbourhood and farm watches. Rural policing is increasingly becoming a specialisation and there is a need for specialist rural intelligence officers such as those in post in Lincolnshire Constabulary. Lincolnshire Constabulary are very orientated towards rural policing and created the post of rural intelligence officer to gather criminal intelligence on rural criminals because they realized that the existing urban based police intelligence apparatus did not gather such information. This increased flow of intelligence on rural crime has allowed Lincolnshire Constabulary to target rural crime with greater resources and efficiency. However, such resources are rare in other forces. As a consequence the police intelligence apparatus does not always capture the intelligence required to police rural criminality. This leads us to consider crime types which have traditionally been associated with the countryside and rurality per se.

\section{Mapping rural crime types}

It is difficult to profile rural crime because it is a multifaceted phenomenon, comprising of farm crime (Donnermeyer \& Barclay, 2005), village crime including forms of rural violence, from assaults at pubs to forms of domestic abuse (Yarwood \& Mawby, 2010), substance abuse and drug production; and various environmental and wildlife crimes (Webster, 1997). Likewise the rural criminal spans social classes and rural geographies. This is exacerbated by the fact that it is difficult gathering and comparing police crime statistics in rural areas (Ashby, 2005). In general terms the volume of crime reported in rural areas is lower than that in urban areas. Crime is therefore in relative terms less common. However, this does not take account population density or non-reporting. Crimes traditionally associated with rurality are a mixture of crimes against the person and property, crimes against animals, and statutory offences. Crimes against the state seldom feature (see table 1 below for descriptive details).

The significance of Table 1 is that preventing and detecting crimes in each of the different categories requires different sets of skills and policing strategies. Moreover, as will be argued, not only is what constitutes rural crime undefined but what constitutes the rural criminal is equally vague. Significantly, Yarwood (2000) concentrates upon (social) constructions of rurality and criminality in Britain arguing that what is culturally constructed as criminality can lead to 
the exclusion of particular groups from rural space. The work of O'Connor and Gray (1989) into rural criminality was focused upon a particular rural community and significantly took a historical and socio-economic stance. Their empirical research established that the public had different images of rural criminality from the socially constructed images of criminality. As a consequence, it is difficult to police what one does not understand and this is of particular note in relation to the hidden enterprise culture in rural areas.

\section{TABLE 1 - A TYPOLOGY OF RURAL CRIMES}

\begin{tabular}{|l|l|}
\hline Crimes against the person: & $\begin{array}{l}\text { These include assault, possession of offensive weapons } \\
\text { and breach of the peace usually of a petty variety. Serious } \\
\text { crimes such as homicide, murder and rape are less } \\
\text { common in rural settings. }\end{array}$ \\
\hline Crimes against property: & $\begin{array}{l}\text { These include theft, fraud (and in particular subsidy } \\
\text { frauds), resetting stolen property, fire-raising, vandalism } \\
\text { and malicious mischief. There are some crimes such as } \\
\text { stock 'rustling' which are unique to the countryside. } \\
\text { Crimes against property are more common in rural areas } \\
\text { which surround urban areas. }\end{array}$ \\
\hline Crimes against animals: & $\begin{array}{l}\text { These include crimes of cruelty and neglect, offences } \\
\text { contrary to the various dogs act, poaching offences, hare } \\
\text { coursing, badger baiting, sheep worrying, wildlife } \\
\text { offences and a barrage of animal health offences. Please } \\
\text { note that in the various acts animals are defined and as a } \\
\text { result some animals are unprotected being considered as } \\
\text { game or vermin. }\end{array}$ \\
\hline Statutory offences: & $\begin{array}{l}\text { These include a barrage of road traffic offences } \\
\text { (particularly drunk driving, disqualified driving and } \\
\text { driving without a licence), offences contrary to the misuse } \\
\text { of drugs act, licensing offences (including the illegal } \\
\text { distillation of liquor), food standards offences and revenue } \\
\text { offences. The latter include avoiding vehicle excise duty, } \\
\text { using red diesel, smuggling and tax avoidance. }\end{array}$ \\
\hline Environmental crimes: & $\begin{array}{l}\text { Such as pollution, effluent spillage, dumping of hazardous } \\
\text { chemicals and fly-tipping. }\end{array}$ \\
\hline
\end{tabular}

\section{Taking Cognisance of the Hidden Enterprise Culture}

As stated above, one of the aims of this paper was to investigate the emerging concept of illegal rural enterprise (McElwee, 2009; McElwee, Smith \& Sommerville, 2011; Smith \& McElwee, 2013). As a direct consequence of these changes it also considers the changing geographies of rural policing in Britain as highlighted by Yarwood (2000: 2011). The hidden 
enterprise culture is comprised of 'off the books', quasi-legal, illegal and immoral entrepreneurial activity. Nevertheless, Williams (2006: 4-5) in his studies of the hidden enterprise culture stopped short of investigating the more illegal aspects of the underground economy and those which occur in a rural context.

Change is an inevitable social process and thus according to Weisheit and Donnermeyer (2000), the paradox of change and continuity is very much a part of rural crime. Illegal rural enterprise (McElwee, Smith \& Sommerville, 2011) is an interesting phenomenon because it spans and thus unites many of the traditional categories of crime discussed above. At the heart of the concept of IRE is the fact that the purpose of much rural criminality is economic in basis. Granted it has a social dimension but primarily generating an alternative income is a significant feature of illegal rural entrepreneurial activity. This allows us to examine the criminal activities of diverse rural criminal groups from a systemic perspective. Doing so allows us to identify links between the groups. However before doing so it is necessary to briefly discuss the invisible links between crime and economic development because the discussion highlights the importance of revaluating how we perceive rural criminals and rural criminality. The IRE concept therefore permits an alternative reading of rural criminality.

\section{Developing a Typology of Rural Criminal Types}

Table 2 below presents a developing 'taxonomy' of possible rural criminal typologies which are useful from a policing perspective. The typologies are based upon the experience of the author as a rural beat officer and a data base compiled by the author of articles in the British Press. The evidence base for the typology was gained through experience and reflection over time. It is based very much on retrospective ethnography (Smith, 2010; Watson, 2012) through experience of policing rural areas; and from reading actual police reports including intelligence reports albeit no actual material or examples are reproduced herein. The Official Secrets Act, 1948 would make the discussion of real events problematic, but the knowledge gained from the reports nevertheless helped inform the methodology and resultant typology. Moreover, this was supplemented by a process of active reflection and by writing up the knowledge from the perspective of an investigatory arm of the police to construct the typology. The material later knowledge later gathered in the field as a researcher coupled with critical readings of the literature confirmed the veracity of the developing typology as it resonated with the author's knowledge of the original intelligence.

It is helpful here to expand upon the typology by providing a descriptive account of the types, based on experience of policing rural areas: 
TABLE 2 - A TAXONOMY OF RURAL CRIMINAL TYPES

\begin{tabular}{|c|c|}
\hline $\begin{array}{l}\text { CRIMINAL } \\
\text { TYPOLOGY }\end{array}$ & DESCRIPTION BY TYPE AND BY ACTIVITY \\
\hline Urban Criminals & $\begin{array}{l}\text { This category of rural criminals is based upon a mixture of readings from the } \\
\text { works of scholars such as Paulson (2007), Smith (2010), Van der Kemp and } \\
\text { Van Koppen (2007), and Abelius (2011), and from observations of the author in } \\
\text { the field. These individuals correspond to Tönnies typology of urban based } \\
\text { rogues. }\end{array}$ \\
\hline Settled Urban Criminals & $\begin{array}{l}\text { This category of rural criminals is based upon observations of the author in the } \\
\text { field and resulted in the publication Smith (2010). These individuals correspond } \\
\text { to Tönnies typology of rural based rogues but with urban values. }\end{array}$ \\
\hline Greenbelt Bandits & $\begin{array}{l}\text { This category of rural criminal is based upon the work of the journalist Ken } \\
\text { Hyder (1997). These individuals correspond to Tönnies typology of rural based } \\
\text { rogues but with urban values. }\end{array}$ \\
\hline Travelling Fraternity & $\begin{array}{l}\text { This category of rural criminals is based upon a mixture of readings from the } \\
\text { works of scholars such as Cluley (2005), Dawson (2000), James (2007), } \\
\text { Mulcahy (2012), and Richardson (2005) and from observations of the author in } \\
\text { the field. These individuals correspond to Tönnies typology of rural based } \\
\text { rogues. }\end{array}$ \\
\hline Rural Criminals & $\begin{array}{l}\text { This category of rural criminal is based upon the observations of the author in } \\
\text { the field and resulted in the publication (Smith, 2010). These individuals } \\
\text { correspond to_Tönnies typology of rural based rogues and offenders. }\end{array}$ \\
\hline Migrant Criminals & $\begin{array}{l}\text { This category of rural criminal is based upon the observations of the author in } \\
\text { the field and resulted in the publication (Smith, 2010). Very little is written of } \\
\text { these criminals who are a mixture of Tönnies typology of rural based rogues } \\
\text { and offenders. }\end{array}$ \\
\hline Village Criminals & $\begin{array}{l}\text { This category of rural criminal is based upon the observations of the author in } \\
\text { the field and resulted in the publication (Smith, 2010). These individuals } \\
\text { correspond to Tönnies typology of rural based rogues and offenders. }\end{array}$ \\
\hline Wildlife / Green Crimes & $\begin{array}{l}\text { This category of rural criminal is based upon the work of Fyfe and Reeves } \\
\text { (2010). This group is difficult to place on Tönnies typology because they are } \\
\text { conducting their craft in a society whose morals have changed with the times. }\end{array}$ \\
\hline Rogue Farmers & $\begin{array}{l}\text { This category of rural criminal is based upon the observations of the author in } \\
\text { the field and resulted in the publications by Smith, (2004), Smith ( 2010), and } \\
\text { Smith \& McElwee (2013). These individuals correspond to_Tönnies typology of } \\
\text { rural based rogues. }\end{array}$ \\
\hline Rogue Entrepreneurs & $\begin{array}{l}\text { This category of rural criminal is based upon the observations of the author in } \\
\text { the field and resulted in the publication (Smith, 2004). These individuals } \\
\text { correspond to Tönnies typology of rural based rogues. }\end{array}$ \\
\hline
\end{tabular}


Urban Criminals: This non homogenous group commits crimes of dishonesty, drugs offences, and status crimes such as dog fighting, badger baiting, and illegal dog racing in the countryside. These include housebreakers, druggies and commercial poachers. Such individuals are often not known by sight to the local police or locals and often use the countryside as a playscape. They are not always identifiable as criminals and frequently change vehicles making it difficult to keep them under surveillance. Urban criminals extract dual value from rurality. Firstly, it provides a venue for targeting victims. The urban criminal is primarily a predator. Thus organised thieves target isolated businesses, farms and houses which are easy targets in comparison to urban businesses because there is less chance of falling foul of police activity. Secondly, the organised urban criminal can use the countryside as a location for setting up a stash for drugs and / or stolen property. Rural premises are ideal for counterfeiting operations or contraband running because of the privacy they afford. In this respect they often rent garages or out buildings from rogue farmers, entrepreneurs or businessmen on a 'no questions asked' basis. Many urban criminals are also into activities which bring them into the countryside such as hare coursing, dog fighting, and badger baiting. Others are poachers either for fun or as a commercial activity. Many are avid 'dogmen' and travel short distances to exercise their animals in open fields. There is a financial as well as reputational element in poaching and dog fighting. Others use the rural area for trials bikes or four-wheel driving activities. There is a considerable degree of interaction between active urban criminals and settled urban criminals in that the urban criminals regularly visit their friends in the countryside either to take part in drug dealing, drug taking, or to lie low when wanted. This increases the passage of criminals through the countryside as business and pleasure intermingle. The urban criminal shares a common heritage with the greenbelt bandits but there is not always a relationship between greenbelt bandits and the local criminal fraternity. Greenbelt bandits are often migrants from other areas. The attraction of the countryside is the anonymity and freedom from surveillance. In terms of police surveillance the urban criminal is a high priority target.

Settled Urban Criminals:_This group consists of urban criminals who have migrated from urban areas and who now live in low cost rented or bought property. Some settled urban criminals operate drugs safe houses or cannabis factories. The settled urban criminal has little contact with rural criminals unless they socialise in local pubs. Some may develop relationships with rogue farmers or businessmen through the rental arrangement. The purpose of their existence is not to stand out. In time the settled urban criminals may become part of the rural criminal underclasses as they learn to adopt rural values and pastimes. These individuals have begun to integrate into the rural criminal population and as such are viewed as harmless hippies. Many are still active on the drug scene. In moving to the rural area they gradually fade into obscurity because they are not generating intelligence reports in sufficient numbers as to be considered 'serious criminals'. This is a self-fulfilling prophecy in that the slowing down of convictions and intelligence reports may falsely confirm this perception. This group should be considered as 'sleepers' for organised criminal groups. At the 2007 SCDEA conference, there was a warning over the rise in rural drug factories. Rural areas are being targeted by organised 
criminals setting up illegal drugs laboratories for the manufacture of designer drugs such as ecstasy, speed, and LSD. Rural areas are considered ideal because the chemicals used in such drugs factories are extremely pungent and explosive. In terms of police surveillance the urban criminal is a medium priority target where known to the authorities.

Green Belt Bandits: The concept of the Greenbelt Bandit was originally coined by Journalist Ken Hyder to refer to wealthy and organised rural crime gangs who had resettled from urban areas. This group consists of wealthy urban criminals who have bought property in the countryside and who use it as a base for their criminal enterprises. Often such individuals can blend into the background because they seldom come to the notice of the police. They often pass themselves off as businessmen. The natural privacy provided by the countryside assists their criminal activities because they are no longer subject to passing police surveillance. These individuals (when known) will remain a police priority. In terms of police surveillance, the urban criminal is a medium priority target where known to the authorities.

Travelling Fraternity: Whilst the issues of crime and the travelling fraternity are contentious, it cannot be ignored. High profile cases suggest that some travelling criminals are part of organized crime groups. These indigenous and highly mobile gangs travel the length and breadth of the country on a seasonal basis committing specific types of thefts. They are highly visible but difficult to interdict because of their modus operandi and because they operate in tight knit family groups. Acting as individuals or in groups of organised criminals, they can be prolific thieves with countrywide contacts. They are often not known by name to local police but are identifiable by type. They frequently provide false names and addresses. They are a police priority but balanced with human rights issues. Because their crimes cross many police boundaries the fecundity of their criminal actions often remain hidden. In terms of police surveillance the urban criminal is a high priority target.

Rural Criminals: This indigenous group hides within plain view and are seldom treated seriously by local police, being known as rogues or worthies. Generally, they will be known to the local police for low level petty offences and will not be considered a threat in relative terms to their urban criminal counterparts. Rural criminals will have less previous convictions and the patterns of conviction will be less dense. Quite often such individuals are not even considered worthy of being generated as 'Nominal's' in police crime intelligence systems. The rural criminal is less visible than their urban counterparts. Many rural criminals live on the poverty line and only live in the countryside because they were re-housed in rural council properties. Unemployment, alcohol and drug abuse is common and drives the rural criminal to commit petty theft. Not all rural criminals emanate from the criminal classes and gravitate towards to fund their interest in cars. Generally the rural criminal does not mix with rogue farmers, rogue entrepreneurs or the alternative business community because of the class differential. In terms of police surveillance, the rural criminal is a medium to low priority target. 
Migrant Criminals: These individuals shelter within the rural migrant community and blend in because of their cultural anonymity. They will invariably have convictions in their homelands but may not have come to police attention in Britain. Migrant criminals are often isolated and as a general rule do not mix with other rural criminal types. They commit low level crimes of predation in their migrant groups and may come to notice for road traffic or alcohol offences. As a consequence the police may not know who / what they are dealing with. In terms of police surveillance, the migrant criminal is a medium priority target.

Village Criminals: This group is highly visible and comprise mostly of young men and youths who commit low level crimes often including anti-social behaviour. They come into conflict with the police but are often not considered to belong to the criminal fraternity. As a result they seldom feature in police intelligence systems. They are a priority in policing terms because they generate complaints. The urban criminal often has a client patron relationship with rural criminals - particularly drug dealers. Many rural drug dealers are part of larger urban drugs gangs and the rural dealer is recruited because of their rural social capital. The village criminal is normally of working or underclass extraction but not always so in the case of middle class cocaine dealers. In terms of police surveillance the village criminal is a high priority target within the imbalanced context of urban and rural criminality, particularly village youths who generate a high number of complaints.

Wildlife / Green Crimes: This is a disparate grouping consisting of egg collectors and collectors of different rare animal and plant species, as well as the new crimes against raptors. Egg collectors adopt sophisticated anti-surveillance techniques and are difficult to detect. The issue of criminalizing landowners and game keepers for wild life crimes is proving controversial.

Rogue Farmers: These loose knit groups of individuals are not always known to the police, but will be known to other government agencies with law enforcement powers. They will invariably have contacts with local criminal networks both urban and rural. As a consequence, they are not regarded as criminals as such. This group is not a police priority.

Rogue Entrepreneurs: These individuals are the hardest to locate in rural areas because they often do not have previous convictions and are known as being dodgy only by local repute. As such they seldom feature in police intelligence systems. Within the community these local businessmen are generally considered beyond repute and are generally not known to the police. Those that are, are usually only suspected as being dishonest. One such individual known to the author operated for 21 years before being caught and convicted. This group is not a police priority.

The reader should note that these typologies are work in progress. Nevertheless, in examining the different rural criminal fraternities in Table 2, it is easy to dismiss them as being unrelated elements of a system. Nothing could be further from the truth. Many (but not all) groups form part of a rural criminal ecology. The first three typologies - urban criminals, settled 
urban criminals and greenbelt bandits share a common heritage in urban criminality and as such can be discussed as one grouping. The divergent typologies identified above are obviously quite broad and appear to lack a unifying paradigm. However, this should not be surprising because as Jobes (2003) articulates - rural communities have divergent social structures. We should not necessarily expect these to conform to, or mirror, urban criminal typologies in either appearance or organisation. Nevertheless, it is possible to group these typologies in terms of whether they are of interest as 'nominals' in police intelligence systems. The level of interest can be graded as high priority; medium priority; low priority; and non-priority. The high and medium priority groups are predatory in nature, whilst the low and non-priority groups are generally not seen in this light.

Rural criminality is not confined to a homogenous criminal underclass as is assumed in relation to urban criminality. Therefore, there is no identifiable 'rural underworld' as such and no rural equivalent of the 'sink estate' scenario which concentrates criminality in identifiable areas. Conversely rural deprivation is not seen as breeding criminal enclaves. The urban marauder thesis (Paulsen, 2007) is the most visible format and because police numbers are scarce in rural settings the criminals have more freedom to roam, as do settled urban criminals, Greenbelt bandits and criminals from the travelling fraternity. Likewise, rogue farmers and rogue rural entrepreneurs have even greater freedom to operate unhindered because they are 'policed' by other agencies such as Trading Standards, The Gang Masters Agency, Food Standards Agency, Ministry Vets, SSPCA/ RSPCA, Animal health, Customs and Excise. It is inevitable that there will be intelligence gaps. One of the only criminal groups who are under constant police surveillance are village criminals, many of whom are youths. It would require a higher level of collaboration between agencies to develop a more sophisticated profile of the rural criminal.

\section{Some Concluding Thoughts on the Changing Typologies of Rural Criminals.}

A major contribution of this work is that a contemporary typology of rural criminals is an innovative addition to the scholarly literature on rural criminality begun by Clinard and others. However those were based on antiquated versions of criminology which saw a greater divide between the rural and the urban which did exist, and a simplistic, functionalist/positivist view of crime. This typology demonstrates the diversity of the rural and the interconnectedness of rural and urban through the modus operandi of offenders. It is hoped that this typology will be useful to both academics and practitioners alike. The main point to take from this article is that the face of rural crime is changing and as a consequence so must the operational methodologies for rural policing. This study also highlights the disjointed nature of official action in the UK. Like Williams (2006, p. 218) this author makes a call for the co-ordination of government thought and action in that there is a pressing need for the coordination of intelligence on rural crime and criminals and an appreciation of the different social strata where such diverse criminality can be encountered. In terms of organised crime, acknowledging the possible existence of a multiple (rural) underworld is vital. Thus whilst there is no single rural criminal sub culture there are a 
number of identifiable criminal types. This has consequences which the police will ignore at their peril if urban crime continues to dominate their time and energies. There is a real danger that the criminally and the entrepreneurially minded can exploit this vacuum for their benefit. There is a need to redress the balance by reallocating resources to rural areas in need and to formulate a sustainable rural policing strategy which involves other rural agencies and partners. If this is not heeded then there is a danger that some rural areas will become the site for increased organised criminal activity. It is significant that what unites many of these disparate rural criminal classes is the concept of illegal rural enterprise and the need to generate alternative incomes. 


\section{References.}

Abelius, V. (2011). To what extent can the use of geographic profiling analysis help solve criminal cases? Bachelor Thesis.

Ashby, D. I. (2005). Policing neighbourhoods: exploring the geographies of crime, policing and performance assessment. Policing and Society 15(4), 413-447.

Baird-Olson, K., (2000). Doing what we've always done: A case study of rural policing. Unpublished study. Washington, DC: National Institute of Justice.

Baumol, W. J. (1990). Entrepreneurship: Productive, unproductive, and destructive. The Journal of Political Economy, 98(5).

Benedict, W. (2000). Perceptions of the police and fear of crime in a rural setting: Utility of a geographically focused survey for police services, planning, and assessment. Criminal Justice Policy Review 11(4), 275-298.

Brogden, M. (1999). Community policing as cherry pie. In Mawby, R. (Ed.), Policing across the world: Issues for the twenty-first century. London: Routledge.

Bristow, A. P. (1982). Rural law enforcement. Boston: Allyn \& Bacon.

Buttle, J. (2006). What is known about policing rural crime: Reviewing the contemporary literature. A Report to the New Zealand Police Rural Liaison. Wellington: New Zealand Police rural Liaison.

Carter, T. J., Donnermeyer, J. F., Phillips, G. H., \& Wurschmidt, T.N. (1982). Rural crime: Integrating research and prevention. Totowa, N.J.: Allenheld, Osmun.

Claydon, E. A. (2011). The detective, the criminal and the countryside:The place of rural britain in the criminal landscape. Paper presented at the University of Leicester Politics of Television Space Conference. April.

Cluley, E. (2005). Irish Travellers' experiences of key service providers. Probation Journal 52, 77-79.

Crank, J. P., Giacomazzj, A., \& Heck, C. (2003). Fear of crime in a nonurban setting. Journal of Criminal Justice 31(3), 249-63.

Davis, R., \& Potter, G. W. (1991). Bootlegging and rural criminal entrepreneurship. Journal of Crime and Justice 14(1), 145-159.

Dawson, R. (2000). Crime and prejudice: Traditional travellers, Derbyshire, UK: Robert Dawson.

Deflem, M. (1999). Ferdinand Tönnies on crime and society: An unexplored contribution to criminological sociology. History of the Human Sciences, 12(3):87-116. 
Donnelly, D. (2005). Policing the Scottish community. In Donnelly, D., \& Scott, K (Eds.), Policing Scotland. Cullompton, UK: Willan Publishing.

Donnermeyer, J. F., \& Barclay, E. (2005). The policing of farm crime. Police Practice and Research 6(1), 3-17.

Donnermeyer, J. F., Jobes, P., \& Barclay, E. (2006). Rural crime, poverty, and communit. In Advancing critical criminology: Theory and application. Lanham, Massachusetts: Lexington Books.

Egmond, F. (2004). Multiple underworlds in the Dutch Republic of the $17^{\text {th }} \& 18^{\text {th }}$ Centuries. In Fijnaut, C., Paoli, L. (Eds.) Organised crime in Europe: Concepts, patterns, and control policies in the European Union and beyond (pp. 77-108). Berlin: Springer

Fenwick, T., Docknell, R., Slade, B., \& Roberts, I. (2011). Rural Policing: Understanding police knowledge and practice in rural communities. Dundee, Scotland: SIPR Research Summary.

Fyfe, N.R., Reeves, A.D. (2010). The thin green line? Police perception of the challenges of policing wildlife crime in Scotland. In R. Mawby \& R. Yarwood (Eds.), Rural policing and policing the rural: A constable countryside (pp. 169-182). Aldershot, England: Ashgate Publishing.

James, Z. (2007). Policing marginal spaces: Controlling gypsies and travellers. Criminology and Criminal Justice 7(4), 367-389.

Jobes, P. (2003). Human ecology and rural policing: A grounded theoretical analysis of how personal constraints and community characteristics influence strategies of law enforcement in rural New South Wales, Australia. Police Practice and Research 4(1), 3-19.

John, T. \& Maguire, M. (2004). The National intelligence model: Key lessons from early research. Home Office Online Report 30/04, http://library.npia.police.uk/docs/hordsolr/rdsolr3004.pdf

Hobbs, D. (1988). Doing the business: Entrepreneurship, the working class, and detectives in the East End of London. Oxford: Oxford University Press.

Hogg, R. (2005). Policing the rural crisis. The Australian and New Zealand Journal of Criminology 4(1), 3-19.

Maguire, B., Faulkner, W., Mathers, R., \& Rowland, C. (1991). Rural police job functions. Police Studies 14, 180-187.

McElwee, G. (2009). Theorising 'value-adding' and 'value-extracting'illegal rural entrepreneurship. Paper presented at the $7^{\text {th }}$ Rural Entrepreneurship Conference, Penrith, England, May.

McElwee, G., Smith, R., \& Sommerville, P. (2011). Theorising illegal rural enterprise: Is everyone at it? International Journal of Rural Criminology, 1(1), 39-59. 
Marshall, B., \& Johnson, S., (2005). Crime in Rural Areas: A Review of the Literature for the Rural Evidence Research Centre, http://www.rerc.ac.uk/findings/documents_reviews/rev2ruralcrime.pdf

Mawby, R. I. (2004). Myth and reality in rural policing: Perceptions of the police in a rural county of England. Policing: An International Journal of Police Strategies \& Management 27(3), 431-446.

Mawby, R. I. (2007). Crime, place and explaining rural hotspots. International Journal of Rural Crime, 1, 21-43.

Mulcahy, A. (2012). Alright in their own place: Policing and the spatial regulation of Irish travelers. Criminology and Criminal Justice 12(3), 307-327.

O’Connor, M., Gray D. (1989). Crime in a Rural Community. Sydney: Federation Press.

Osgood, D. W., Chambers, J. M. (2000). Social Disorganisation outside the metropolis: An analysis of rural youth violence. Criminology 38(1), 81-115.

Paulsen, D. (2007). Improving geographic profiling through commuter/marauder prediction. Police Practice and Research: An International Journa, 8(4), 347-357.

Payne, B. K., Berg, B. L., \& Sun, I. J. (2005). Policing in small town America: Dogs, drunks, disorder, and dysfunction. Journal of Criminal Justice 33(1): 31-41.

Ratcliffe, J. (2003). Trends \& issues in crime and criminal justice. http://www.aic.gov.au/publications/current\%20series/tandi/241260/tandi248/view\%20paper.aspx

Richardson, J. (2005). Policing Gypsies and Travellers. Paper presented at the Housing Studies Association Conference, York, England.

Smith, R. (2004). Rural rogues: A case story on the "smokies" trade. International Journal of Entrepreneurial Behaviour \& Research 10(4), 277-294.

Smith, R. (2008). A case study on 'illegal pluriactivity' in the farming community.Paper presented at the $6^{\text {th }}$ Rural Entrepreneurship Conference, Dumfries, Scotland.

Smith, R., (2010). Policing the changing landscape of rural crime: A case study from Scotland. International Journal of Police Science \& Management 12(3), 373-387.

Smith, R. (2011). Investigating financial aspects of dog-fighting in the UK: A research note. Journal of Financial Crime 18(4), 336-346.

Smith, R., \& Whiting, M. (2013). Documenting and investigating the entrepreneurial trade in illegal veterinary medicines in the United Kingdom and Ireland. Handbook of Veterinary Business and Enterprise. Philadelphia: Elsevier. 
Smith, R., McElwee, G. (2013). Confronting social constructions of rural criminality: A case story on illegal pluriactivity in farming. Sociologica Ruralis, 53(1), 112-134.

Sorokin, P., \& Zimmerman, C. C. (1929). Principles of rural-urban Sociology. New York: H. Holt.

Sorokin, P., Zimmerman, C. C., \& Galpin, C. G. (1931). A systematic sourcebook in Rural Sociology. Minneapolis: University of Minnesota Press.

Thurman, Q., \& McGarrell, E. (1997). Community policing in a rural setting. Cincinnati: Anderson Publishing Co.

Tönnies, F., (1887). Gemeinschaft und Gesellschaft [translated in 1957 as Community and Society] Leipzig: Fues's Verlag.

Van der Kemp, J. J., Van Koppen P. J. (2007). Fine tuning geographical profiling. Criminal Profiling, Part IV, 347-364.

Webster, D. (1997). The looting and smuggling and fencing and hoarding of impossibly precious, feathered and scaly wild things. Trends in Organized Crime 3(2), 9-10.

Weisheit, R. A., \& Wells, L.E. (1999). Future of crime in rural America. Journal of Crime \& Justice 22(1), 1-26.

Weisheit, R. A., \& Donnermeyer, J. F. (2000). Change and continuity in crime in rural America. In G. LaFree, J. Short, R.J. Bursik, \& R. Taylor (Eds), Criminal Justice 2000 (pp. 309-358). Washington, D.C.: National Institute of Justice, U.S. Department of Justice.

Weisheit, R. A., \& Falcone, D.N. (undated). Rural crime and rural policing. http://www.ncjrs.gov/pdffiles/rcrp.pdf.

Williams, C. C., (2006). The hidden enterprise culture: Entrepreneurship in the underground economy. Cheltenham: Edward Elgar.

Yarwood, R. (2000). Crime and policing in the British countryside: Some agendas for contemporary geographical research. Sociologia Ruralis 41(2), 201-219.

Yarwood, R., \& Edwards, B. (1995). Voluntary action in rural areas: The case of Neighbourhood Watch. Journal of Rural Studies 11(4), 447-460.

Yarwood, R., \& Gardner, G. (2000). Fear of crime, cultural threat and the countryside. Area 2, 403-411.

Yarwood, R., \& Cozens, C. (2004). Constable countryside? Police perspectives on rural Britain. In L.Holloway and M. Kneafsey (eds.), Geographies of Rural Cultures and Societies (pp. 145 - 172). Aldershot, England: Ashgate Publishing. 
Developing a Working Typology of Rural Criminals: From a UK Policing Intelligence Perspective -- Smith

Yarwood, R., Mawby, R. I. (Eds.). (2010). Constable countryside? Police perspectives on rural Britain. Aldershot, England: Ashgate Publishing. 